\title{
PELESTARIAN WARISAN BUDAYA DI LOCAL STUDIES CENTER DENGAN PEMANFAATAN MEDIA SOSIAL
}

\author{
Widiatmoko Adi Putranto \\ Program Studi Kearsipan, Sekolah Vokasi, Universitas Gadjah Mada \\ widiatmokoputranto@ugm.ac.id \\ Indah Novita Sari \\ Program Studi Kearsipan, Sekolah Vokasi, Universitas Gadjah Mada \\ indah.novita.s@mail.ugm.ac.id
}

\begin{abstract}
The massive development of information technology today gives essential impact in various management practices including the approach of preservation in many cultural institutions. This paper aims to study how local studies center as one of the cultural institutions may reconsider new challenges and possibilities in using social media towards the dynamics of users' behavior and perspective as one of the approaches to preserve its collections. Local studies center has numerous collections of information resources in different forms such as book, archive or even object which are rare, historical and unique. Besides its positions as cultural heritage, those collections can give valuable contribution for public benefits. As one of the approaches to support preservation efforts, local studies center can use social media as one of the mediums to promote its collections. However, instead of viewing social media usage as a technical concept or reformatting tool only, its management should be considered as a part of developing interactive communication and relationship with the users, opening wider access and improving awareness regarding the existence of cultural heritage.
\end{abstract}

Keywords: social media, preservation, cultural heritage, promotion, local studies centre

\section{Intisari}

Perkembangan besar-besaran dalam teknologi informasi saat ini memberikan dampak penting dalam berbagai praktik manajemen termasuk pendekatan pelestarian di banyak lembaga kebudayaan. Makalah ini bertujuan untuk mempelajari bagaimana Local Studies Center sebagai salah satu lembaga kebudayaan dapat mempertimbangkan kembali tantangan dan kemungkinan baru dalam menggunakan media sosial terhadap dinamika perilaku dan perspektif pengguna sebagai salah satu pendekatan untuk melestarikan koleksi. Local Studies Center memiliki banyak koleksi sumber informasi dalam berbagai bentuk seperti buku, arsip atau bahkan objek yang langka secara historis dan unik. Selain posisinya sebagai warisan budaya, koleksi tersebut dapat memberikan kontribusi yang berharga untuk keuntungan publik. Sebagai salah satu pendekatan untuk mendukung upaya pelestarian, Local Studies Center dapat menggunakan media sosial sebagai salah satu media untuk mempromosikan koleksinya. Namun, alih-alih melihat penggunaan media sosial sebagai konsep teknis atau alat pemformat ulang saja, dalam manajemennya harus dianggap sebagai bagian dari pengembangan komunikasi interaktif dan hubungan dengan pengguna, membuka akses yang lebih luas dan meningkatkan kesadaran mengenai keberadaan warisan budaya.

Kata kunci: media sosial, pelestarian, warisan budaya, promosi, Local Studies Center 


\section{PENDAHULUAN}

Upaya pelestarian koleksi warisan budaya dimulai dengan kesadaran akan keberadaan dan rasa keterhubungan dari masyarakat secara umum dan pengguna pada khususnya. Dampak dari perubahan esensial dalam cara berkomunikasi sebagai akibat dari perkembangan teknologi terhadap insitusi kebudayaan seperti perpustakaan, arsip maupun museum telah banyak diperdebatkan. Local studies centre, yang merupakan konsep pusat informasi yang menggabungkan perpustakaan, arsip dan museum bertanggung jawab terhadap keberadaan sejumlah koleksi warisan budaya yang penting dalam material berbentuk kertas, artefak dan objek lainnya. Eksistensi local studies center diharapkan mampu menawarkan pilihan lain pagi pengguna sebagai wadah dari beragam sumber informasi alternatif. Namun, koleksi yang dimiliki local studies center kurang mendapatkan perhatian, akses dan pengakuan yang layak dari khalayak ramai sehingga kunjungan maupun kesadaran akan keberadaan koleksi tersebut cenderung masih rendah.

Beragam penelitian telah dihelat dalam satu dekade terakhir memperdebatkan bagaimana institusi kebudayaan dalam pengelolaan koleksinya mesti merespon kemunculan format elektronik dan media sosial secara konstruktif agar memberikan manfaat dan meningkatkan kemudahan akses bagi pengguna. Format elektronik menawarkan pilihan digitalisasi-alih media pada koleksi fisik yang berimbas pada kemudahan akses dan penyebaran informasi. Meskipun kebanyakan institusi kebudayaan menganut keyakinan yang seragam pada dampak positif hal ini namun dalam prosesnya, institusi kebudayaan cenderung abai terhadap yang mengakomodasi perspektif pengguna. Sebagai akibatnya, transformasi promosi pada media sosial lebih dimaknai sebagai isu teknis dan mengesampingkan dimensi sosial yang ada. Untuk mengikutsertakan serta meraih lebih banyak pengguna, pemahaman terhadap selera dan kebutuhan pengguna perlu mendapatkan porsi yang lebih signifikan.

Kemunculan media sosial di era Internet memberikan pilihan bagi institusi kebudayaan dalam menyediakan akses, membangun jejaring maupun mempromosikan koleksi yang dimiliki. Sebagai contoh, Instagram merupakan salah satu media sosial dengan jutaan pengguna di seluruh dunia. Instagram mengakomodasi kebutuhan pengguna untuk berbagi dengan fokus pada penyajian visual berupa foto. Pengguna dapat mengambil, menyunting dan berbagi sambil memberikan komentar ataupun like diantara pengguna lain. Instagram memiliki kekuatan dalam penyajian gambar yang mempertimbangkan elemen estetika yang dalam konteks bisnis dapat menarik perhatian pengguna. Salah satu karakteristik media social sebagai salah satu media berbasis Internet adalah keleluasaan dan kebebasan yang dimilika pengguna untuk sama-sama menjadi bagian dari platform tersebut, dibandingkan dengan halaman situs resmi ataupun katalog online yang terkesan kaku dan cenderung memiliki satu arah sudut pandang.

Riset tentang media sosial juga telah dilakukan dalam berbagai perspektif dengan beragam konsep yang melibatkan sistem, pengguna dan pemanfaatan media sosial sendiri. Media sosial secara konseptual merujuk pada sekelompok aplikasi berbasis internet yang dibangun berdasarkan 
web 2.0 (Sriram, V., 2016). Implikasi beragam konsep yang telah digali dalam penelitian tentang media sosial adalah kekayaan kajian dan optimalisasi pemanfaatan media sosial untuk kebutuhan organisasi. Faktanya, penggunaan media sosial telah intensif dipakai sejak tahun 2003 (Boyd \& Ellison dalam Li, E. Y., Loh, S., Evans, C., \& Lorenzi, F., 2013). Aplikasi media sosial memungkinkan pengguna untuk berbagi, mengelola konten dan ikut berpartisipasi aktif dalam komunikasi berbasis elektronik.

Beberapa peneliti mencoba untuk mengklasifikasikan media sosial berdasarkan tipe karakteristik. Kaplan and Haenlein dalam Li, E. Y., Loh, S., Evans, C., \& Lorenzi, F. (2013) memasukkan 6 tipe media sosial yaitu collaborative projects, blogs, content communities, social networking sites, virtual game worlds, dan virtual social worlds. Collaborative project merujuk pada website yang memungkinkan berbagai pengguna untuk melakukan penyuntingan atau berkontribusi terhadap isi, contohnya wikipedia. Selanjutnya, ada blog yaitu halaman online yang memungkinkan individu untuk mengekspresikan pengalaman kepada publik. Ketiga, content communities yang memungkinkan pengguna berbagi konten dengan orang lain, misalnya YouTube. Keempat, social networking sites yang memungkinkan pengguna terhubung dengan orang lain, contohnya Facebook dan Twitter. Kelima, virtual game worlds yang merujuk pada ruang maya yang berisi komunitas pecinta game. Terakhir adalah virtual social words memungkinkan sekumpulan orang untuk berkumpul di ruang maya berdasarkan kegemaran kelompok tersebut.

Beragam tipe media sosial yang telah dipaparkan sebelumnya menunjukkan terdapat segmentasi pasar pengguna media sosial. Berbicara dalam konteks Indonesia, kuantitas pengguna media sosial bisa dikatakan cukup besar. Survey yang dilakukan Asosiasi Penyedia Jasa Internet Indonesia pada tahun 2016, didapatkan data bahwa pengguna internet di Indonesia sebesar 132.700.000 dengan besaran pengguna media sosial yaitu 129.200 .000 atau 97,4\%. Lebih lanjut, Asosiasi Penyedia Jasa Internet Indonesia (2016) mengeluarkan data besaran pengguna media sosial beserta aplikasi yang sering dikunjungi oleh pengguna pada gambar 1:
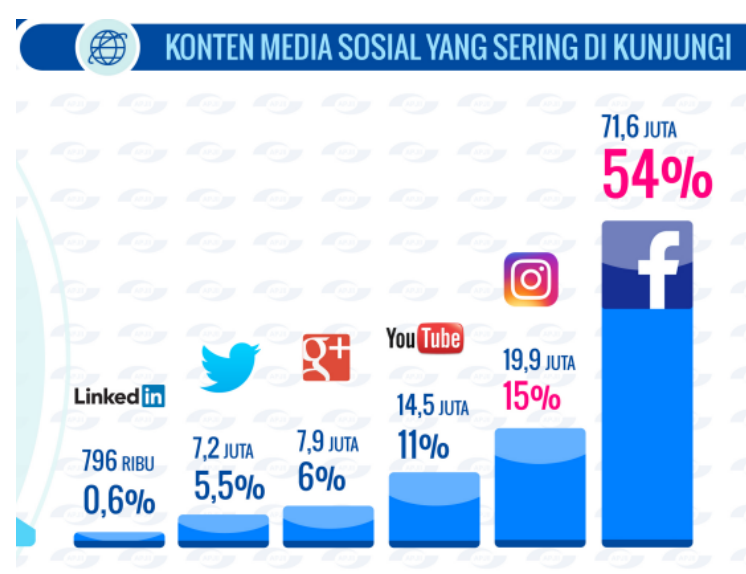

\section{Gambar 1 \\ Aplikasi media sosial yang sering dikunjungi dan jumlah penggunanya}

Data jumlah pengguna dan aplikasi yang digunakan pada tahun 2016 menunjukkan bahwa media sosial memiliki daya tarik tersendiri dalam dunia maya. Fenomena ledakan pengguna di media sosial ini kemudian menjadi menarik untuk dikaji peluangnya ketika dikaitkan dengan upaya pelestarian sumber informasi pada local studies center.

Beberapa studi yang berhubungan dengan promosi dengan pemanfaatan media sosial yang dilakukan oleh institusi perpustakaan, arsip dan museum telah dilakukan sebelumnya. Riset yang dilakukan Lowe (2014) tentang bagaimana melibatkan pengguna muda di Museum Norwegia menggunakan media 
sosial menunjukkan bahwa Instagram dapat digunakan untuk mengeksplorasi kebutuhan pengguna dalam lingkungan urban dengan data warisan budaya. Di sisi lain, Sriram (2016) yang berusaha mengulas tentang pemasaran KN Raj Library dengan menggunakan media sosial mendemonstrasikan bahwa beragam web 2.0 dan media sosial merupakan alat yang tepat dalam pemasaran sumber daya dan layanan di perpustakaan. Selain itu, beragam media sosial yang populer terbukti dapat menjadi alat pemasaran dan publisitas yang efektif dengan sebaran informasi yang luas untuk perpustakaan.

Implikasi dari hadirnya teknologi informasi dengan didukung oleh perkembangan aplikasi berbasis sosial media adalah peningkatan akses terhadap konten informasi dari institusi kebudayaan, termasuk local studies center. Harris (6454) memperlihatkan beberapa masalah yang berhubungan dengan akses dan preservasi. Lebih lanjut dijelaskan oleh Steward, C. (2012) bahwa pengelola informasi memiliki ketakutan tersendiri ketika terlalu membuka akses terhadap koleksi mereka. Hal ini disebabkan oleh rapuhnya beberapa koleksi langka yang memang telah berusia puluhan tahun. Permasalahan yang timbul ketika akses fisik terhadap koleksi kebudayaan dipersulit adalah relevansi dan kekayaan isi koleksi budaya juga terancam menghilang seiring berjalannya waktu.

Beberapa kajian tentang preservasi telah dilakukan di berbagai negara dengan melibatkan unsur hadirnya teknologi informasi. Ress (2015) mencoba mengeksplorasi cara untuk meningkatkan akses dan kegunaan dari sumber daya di perpustakaan. Beberapa aplikasi digunakan seperti BibilioBoard dan Historypin sebagai strategi untuk meningkatkan akses terhadap koleksi. Selain itu, pustakawan memainkan peran kunci dalam memfasilitasi sumberdaya dan akses sehingga bisa digunakan secara luas.

Studi tentang penggunaan media sosial memang telah banyak dilakukan dengan berbagai sudut pandang. Mayoritas kajian masih didasarkan pada kebutuhan individu dalam akses informasi dan rekreasi, pengembangan sistem untuk perluasan akses dan identifikasi aplikasi media sosial yang banyak digunakan oleh lembaga informasi. Namun, penggunaan media sosial sebagai upaya pelestarian warisan budaya di Local Studies Center masih belum banyak dikaji. Local studies center merujuk pada lembaga informasi yang memiliki koleksi berupa arsip, artefak dan buku (Perez, M. J. V. 2012). Pemahaman tentang peluang dan tantangan dalam kegiatan preservasi dengan memanfaatkan media sosial ini, diharapkan dapat menjadi pengetahuan baru bagi pengelola informasi. Media sosial memungkinkan peningkatan akses terhadap isi informasi (preservasi isi) dan mengurangi kontak berlebihan dari pengguna terhadap fisik informasi (preservasi fisik).

Penelitian ini bertujuan untuk mendiskusikan dan mengkaji berbagai tantangan dan kemungkinan utama dalam penggunaan media sosial dalam kaitannya dengan promosi dan akses terhadap koleksi warisan budaya dalam beragam bentuk dari arsip, buku, peta, hingga artefak yang dimiliki local studies centres. Meskipun penggunaan media sosial sebagai sarana promosi memberikan kemudahan sarana akses, berbagi dan fleksibilitas, melimpah ruahnya sumber informasi dalam bentuk elektronik memberikan tantangan yang esensial dalam hal kurasi dan presentasi. Upaya preservasi dapat dimulai dengan meningkatkan visibilitas dan akses kepada pengguna dan dengan melimpah ruahnya pengguna media sosial dan koleksi digital, menjaga warisan budaya 
supaya tetap relevan dengan masyarakat akan memberikan dampak signifikan dan kesadaran terhadap keberadaan warisan budaya dan local studies centre sendiri agar tetap relevan dan lestari diantara pengguna.

\section{BAHAN DAN METODE PENELITIAN}

Metode penelitian mutlak diperlukan untuk membangun penjelasan terhadap permasalahan yang ada. Penelitian ini dilakukan secara kualitatif dengan menggunakan metode studi pustaka, survei lapangan sekaligus wawancara kepada pihak-pihak terkait dan partisipasi secara langsung dalam media sosial. Pertama, perlu untuk mencari data dan buku-buku yang terkait dengan tema penelitian. Teknik pengumpulan data dapat dilakukan dengan wawancara, observasi ataupun survei. Selain itu, penelitian kualitatif bertujuan untuk mendapatkan pemahaman yang sifatnya umum terhadap kenyataan sosial dari perspektif partisipan. Menurut Anderson (2016b, p. 12), melakukan analisa terhadap dinamika media sosial memerlukan partisipasi sekaligus observasi secara langsung terhadap sejumlah media sosial yang dimiliki institusi-institusi terkait. Ketiga penulis merupakan pengguna beberapa media sosial secara aktif.

Dalam proses membangun sebuah analisis, penjelasan secara komprehensif tidak hanya dijelaskan dengan satu faktor tetapi beberapa faktor. Dalam penelitian ini, pembahasan secara menyeluruh akan disajikan melalui sebuah argumen ilmiah. Melalui argumen yang tepat diharapkan mampu mencapai hasil studi yang maksimal. Argumen itu sendiri merujuk pada data-data ilmiah. Hal yang perlu diperhatikan ketika berhadapan dengan data ilmiah merujuk pada fakta-fakta yang merupakan bahan dasar penulisan. Data-data yang telah diseleksi kemudian dirangkai berdasarkan urutan kronologis agar dapat menjelaskan fakta-fakta terjadi. Setelah didapat deskripsi yang cukup memadai, barulah fakta-fakta sejarah tersebut dianalisis secara komprehensif menurut topik permasalahan utama sehingga pada akhirnya didapat sebuah kesimpulan yang dapat menjawab permasalahan.

\section{HASIL DAN PEMBAHASAN}

Sejumlah Local Studies Center diketahui telah menyadari signifikansi dari keberadaan media sosial serta pentingnya memiliki pengelolaan media sosial yang layak dan sesuai. Senada dengan website, media sosial dianggap mampu membuka akses yang lebih besar, lebih cepat dan lebih mudah kepada pengguna. Akan tetapi, media sosial dianggap memiliki satu karakteristik yang lebih memberikan keuntungan dibandingkan website atau katalog dengan database besar, yaitu posisi media sosial dimana baik pengelola maupun pengguna sama-sama dapat memiliki maupun mengoperasikannya (Anderson, 2016a, p. 6; Ahenkorah-Marfo \& Akussah, 2016, p. 551). Hal ini dianggap menimbulkan kesan yang lebih tidak intimidatif dan kesan kesetaraan di antara institusi dan para penggunanya dalam berkomunikasi. Disamping itu, media sosial menjadi platform yang lebih sederhana dibandingkan website dalam hal keberadaan jumlah informasi dan bagaimana pengguna dapat menemukannya (Lamont \& Nielsen, 2015, p. 107). Di satu sisi, website menawarkan kuantitas informasi yang sangat komprehensif sedangkan media sosial memiliki jumlah informasi yang lebih terbatas. Akan tetapi, keterbatasan ini justru dapat memberikan kesan yang lebih memudahkan dibandingkan informasi dalam jumlah besar yang terkadang justru membingungkan pengguna. Peta pemanfaatan serta dinamika pengelolaan media sosial di 
sejumlah Local Studies Center yang ada di Yogyakarta dapat dilihat pada tabel 1 dan tabel 2.

Tabel 1. Jenis dan pengelola media sosial di Local Studies Center

\begin{tabular}{|c|c|c|c|c|c|}
\hline \multirow[t]{2}{*}{ Local Studies Center } & \multicolumn{3}{|c|}{ Jenis Media Sosial yang dimiliki } & \multirow[t]{2}{*}{ Website } & \multirow[t]{2}{*}{ Pengelola } \\
\hline & Instagram & Facebook & Twitter & & \\
\hline $\begin{array}{l}\text { Museum Sonobudoyo } \\
\text { (LSC 1) }\end{array}$ & $\sqrt{ }$ & $\sqrt{ }$ & $\sqrt{ }$ & $\sqrt{ }$ & $\overline{\text { Ada }}$ \\
\hline Museum Dewantara & $\sqrt{ }$ & $\sqrt{ }$ & $\sqrt{ }$ & $\sqrt{ }$ & Sahabat \\
\hline Kirti Griya (LSC 2) & & & & & Museum \\
\hline Arsip UGM (LSC 3) & & & & & Ada \\
\hline $\begin{array}{l}\text { Hatta Corner - } \\
\text { Perpustakaan UGM } \\
\text { (LSC 4) }\end{array}$ & $\sqrt{ }$ & $\sqrt{ }$ & $\sqrt{ }$ & $\sqrt{ }$ & Ada \\
\hline Museum UGM (LSC 5) & $\begin{array}{c}\sqrt{ } \\
\text { Sudah tidak } \\
\text { aktif }\end{array}$ & $\begin{array}{c}\sqrt{ } \\
\text { Sudah } \\
\text { tidak aktif }\end{array}$ & $\begin{array}{c}\sqrt{ } \\
\text { Sudah } \\
\text { tidak aktif }\end{array}$ & $\begin{array}{l}\text { Tidak } \\
\text { ada }\end{array}$ & Tidak \\
\hline
\end{tabular}

Sumber: Data wawancara dan survei lapangan ke Local Studies Center terkait yang diolah

Tabel 2. Pemanfaatan media sosial di Local Studies Center

\begin{tabular}{|c|c|c|c|}
\hline Local Studies Center & Model Pengelolaan & $\begin{array}{c}\text { Kesadaran } \\
\text { Pemanfaatan }\end{array}$ & Indikator Dampak \\
\hline $\begin{array}{l}\text { Museum Sonobudoyo } \\
\text { (LSC 1) }\end{array}$ & $\begin{array}{l}\text { Menggunakan } \\
\text { bahasa formal }\end{array}$ & $\begin{array}{l}\text { Menyadari media } \\
\text { sosial yang tengah } \\
\text { berpengaruh di } \\
\text { kalangan pengguna }\end{array}$ & $\begin{array}{l}\text { Membuka akses informasi } \\
\text { secara cepat dan efisien. } \\
\text { Misalnya kegiatan pameran } \\
\text { Mengedukasi }\end{array}$ \\
\hline $\begin{array}{l}\text { Museum Dewantara Kirti } \\
\text { Griya (LSC 2) }\end{array}$ & $\begin{array}{l}\text { Penggunaan bahasa } \\
\text { yang luwes dan } \\
\text { tidak kaku }\end{array}$ & $\begin{array}{l}\text { Menyadari media } \\
\text { sosial yang tengah } \\
\text { berpengaruh di } \\
\text { kalangan pengguna }\end{array}$ & $\begin{array}{l}\text { Membuka akses informasi } \\
\text { secara cepat dan efisien } \\
\text { Mengedukasi }\end{array}$ \\
\hline Arsip UGM (LSC 3) & $\begin{array}{l}\text { Menggunakan } \\
\text { bahasa formal dan } \\
\text { mudah dipahami }\end{array}$ & $\begin{array}{l}\text { Menyadari media } \\
\text { sosial yang tengah } \\
\text { berpengaruh di } \\
\text { kalangan pengguna }\end{array}$ & $\begin{array}{l}\text { Membuka akses informasi } \\
\text { secara cepat dan efisien } \\
\text { Mengedukasi }\end{array}$ \\
\hline $\begin{array}{l}\text { Hatta Corner - } \\
\text { Perpustakaan UGM (LSC } \\
\text { 4) }\end{array}$ & $\begin{array}{l}\text { Menggunakan } \\
\text { bahasa formal }\end{array}$ & $\begin{array}{l}\text { Menyadari media } \\
\text { sosial yang tengah } \\
\text { berpengaruh di } \\
\text { kalangan pengguna }\end{array}$ & $\begin{array}{l}\text { Membuka akses informasi } \\
\text { secara cepat dan efisien } \\
\text { Mengedukasi }\end{array}$ \\
\hline Museum UGM (LSC 5) & $\begin{array}{l}\text { Menggunakan } \\
\text { bahasa formal }\end{array}$ & $\begin{array}{l}\text { Menyadari media } \\
\text { sosial yang tengah } \\
\text { berpengaruh di } \\
\text { kalangan pengguna }\end{array}$ & $\begin{array}{l}\text { Membuka akses informasi } \\
\text { secara cepat dan efisien } \\
\text { Mengedukasi }\end{array}$ \\
\hline
\end{tabular}

Sumber: Data wawancara dan survei lapangan ke Local Studies Center terkait

Selain itu, dari peta pemanfaatan media sosial di Local Studies Center yang ada di atas, dapat ditemukan sejumlah poin analisa tentang pemanfaatan media sosial dalam kaitannya dengan pengembangan kebijakan, promosi koleksi dan sasaran pengguna guna terciptanya peningkatan kesadaran akan pentingnya upaya pelestarian dan keberlangsungan koleksi warisan budaya di masa depan.

\section{Kesadaran pemanfaatan media sosial}

Pengguna informasi pada abad 21 memiliki karakteristik yang berbeda dengan abad-abad sebelumnya. Kehadiran teknologi dan internet menjadikan masyarakat pada abad 21 berinteraksi dan berpartisipasi dalam ruang-ruang yang ada di dunia maya. Hal ini senada dengan pendapat yang diungkapkan oleh Sloniowski dalam 
(Kwanya, Stilwell, \& Underwood, 2015) bahwa dalam lingkungan seperti ini, informasi diciptakan, dibagi, diolah dan dibagi kembali melalui interaksi sosial dan jaringan. Media sosial yang dikembangkan melalui internet menjadi ruang publik baru untuk berbagi pengetahuan.

Pengelola informasi juga menyadari kebutuhan dalam pelestarian isi koleksi yang memerlukan partisipasi aktif pengguna. Oleh karena itulah, media sosial menjadi penting untuk dimanfaatkan dan diharapkan memberikan kontribusi lebih dalam pengembangan pengetahuan. Lebih jauh, ternyata pengelola media sosial pada museum sonobudoyo dan museum Dewantara Kirti Griya juga telah menyadari bahwa penggunaan media sosial berpengaruh terhadap minat berkunjung dan dapat dijadikan alat promosi yang baik. Selain itu, media sosial juga menunjukkan eksistensi dari suatu institusi budaya (pengelola informasi arsip UGM). Kepentingan media sosial inilah yang mendasari para pengelola informasi pada Local Studies Center telah memiliki akun media sosial masing-masing dengan frekuensi posting yang berbeda-beda didasarkan pada kebutuhan organisasi. Namun, tidak dapat dipungkiri, implementasinya memiliki kekurangan karena keterbatasan SDM. Sebagai contoh, museum UGM yang saat ini sudah tidak aktif media sosialnya serta website museum Dewantara Kirti Griya yang terakhir memiliki posting berita pada tahun 2016. Hal inilah yang perlahan perlu diperbaiki untuk keberlangsungan Local Studies Center.

\section{Kebijakan dan pengelolaan media sosial}

Meskipun secara umum kebanyakan Local Studies Center telah memanfaatkan media sosial untuk mengembangkan jaringan sekaligus mempermudah akses, akan tetapi institusi-institusi tersebut belum memiliki kebijakan tertulis yang secara khusus mengatur tentang pengelolaan media sosial. Di Museum Sonobudoyo, satu orang staff dengan latar belakang Teknologi Informasi (TI) memiliki tanggung jawab atas pengelolaan media sosial sekaligus subjektivitas atas interpretasi pemilihan konten yang dianggap layak unggah. Hal yang sama juga terjadi di Museum Dewantara Kirti Griya dan Arsip Universitas, dimana standar konten sangat tergantung pada subjektivitas staff pengelola media sosial tanpa adanya panduan tertulis yang dapat diacu. Di Arsip Universitas Gadjah Mada, pengelola media sosial memiliki sejumlah tugas lainnya dan tidak hanya memiliki tugas utama untuk mengelola media sosial. Selain itu, terdapat persamaan lain di antara semua Local Studies Center dimana staff pengelola media sosial belum mendapatkan pelatihan secara khusus dan di museum Dewantara Kirti Griya, dikatakan bahwa staff melakukan pengelolaan secara 'learning by doing'.

Selain itu, di museum Dewantara Kirti Griya dan museum Sonobudoyo, media sosial setidaknya mengunggah satu hal baru setiap minggunya. Meskipun begitu, tidak ada peraturan tertulis mengenai keharusan melakukan hal tersebut. Di Arsip Universitas Gadjah Mada juga berlaku hal yang sama. Pengelola juga akan menunggah informasi lebih cepat dan lebih banyak dalam periode satu minggu apabila memungkinkan. Hal yang menarik untuk dicatat adalah bahwa di baik di museum Sonobudoyo, museum Dewantara Kirti Griya dan di Arsip Universitas Gadjah Mada, pengelola mengakui bahwa media sosial membuka akses komunikasi yang lebih interaktif sekaligus memangkas alur birokrasi bagi para pengguna yang tertarik dengan institusi tersebut. Sejumlah saran, kritik maupun apresiasi 
sering diterima oleh para pengelola yang kemudian disampaikan kepada pihak terkait. Di museum Sonobudoyo, sejumlah pengguna menanyakan prosedur penelitian melalui media sosial institusi tersebut. Dapat dikatakan bahwa media sosial memberikan manfaat bagi kedua belah pihak untuk saling berdialog (Ahenkorah-Marfo \& Akussah, 2016, p. 551) terkait dengan koleksi maupun akses di institusi tersebut.

Hal yang berbeda terjadi dalam penentuan bahasa yang digunakan dalam unggahan di media sosial. Pengelola media sosial di museum Sonobudoyo beranggapan bahwa sebagai institusi pemerintah, setiap caption dalam unggahan mesti menggunakan bahasa resmi dan formal. Di sisi lain, pengelola media sosial di museum Dewantara Kirti Griya justru menunjuk bahwa penggunaan bahasa yang luwes dan tidak kaku dapat membuka interaksi serta menarik lebih banyak pengguna untuk tertarik mengakses media sosial yang dimiliki institusi. Di Hatta Corner yang belum memiliki media sosial sendiri, pengelolaan akhirnya dilakukan melalui kolaborasi dengan organisasi induk mereka yaitu Perpustakaan UGM.

Secara khusus, meskipun mengunggah koleksi dapat meningkatkan kesadaran pengguna akan keberdaan koleksi tersebut dan upaya pelestariannya, pengelola media sosial di museum Sonobudoyo mengungkapkan adanya kekhawatiran upaya peniruan dan duplikasi dari adanya foto koleksi warisan budaya yang diunggah ke media sosial. Sehingga, banyak konten potensial yang menarik namun hingga saat ini belum dapat diunggah semuanya.

\section{Kesadaran kurasi, promosi dan perannya dalam membantu upaya pelestarian}

Hampir semua Local Studies Center menghadapi tantangan yang sama dikarenakan minimnya sumber daya manusia yang dimiliki, yaitu mengunggah konten yang sama untuk semua media sosial yang dimiliki tanpa mempertimbangkan karakter khas yang menjadi kekuatan media sosial tersebut. Padahal, secara umum dapat dikatakan bahwa setiap media sosial membutuhkan pendekatan yang berbeda dalam kaitannya dalam tiap-tiap hal yang diunggah. Instagram misalnya, memiliki kekuatan yang besar dalam penampilan visual yang lebih menarik bagi Net Generation (Mi \& Nesta, 2006) sehingga deskripsi yang diberikan dapat sekedar menjadi pendukung gambar yang ditampilkan. Di sisi lain, Twitter misalnya memiliki kekuatan pada deskripsi yang singkat, informatif dan up to date sehingga dapat lebih dimanfaatkan untuk informasi-informasi yang deskriptif. Museum Sonobudoyo dan museum Dewantara Kirti Griya menyadari bahwa diperlukan kurasi atas konten unggahan dan pendekatan dalam teknik penampilannya untuk lebih dapat menarik perhatian pengguna serta mengoptimalkan kekuatan tiap-tiap media sosial yang dimiliki. Di museum Dewantara Kirti Griya, beberapa informasi secara khusus hanya dibagi pada kelompok tertutup Sahabat Museum di WhatsApp. Museum yang sama juga mencoba menciptakan sejumlah hashtag yang dianggap menarik minat pengguna di Instagram.

Kebanyakan Local Studies Center masih memberikan porsi yang lebih besar kepada unggahan terkait informasi kegiatan dan belum memaksimalkan promosi atas koleksi warisan budaya yang dimiliki. Lebih lanjut, seperti yang sudah didiskusikan sebelumnya, kurasi atas apa yang dianggap layak unggah dan penilaian estetikanya dibebankan pada subjektivitas tiap-tiap pengelola. Pengelola Arsip Universitas Gadjah Mada menganggap bahwa hal yang diunggah 
mesti relevan dan memiliki konteks dengan situasi dan kondisi yang tengah terjadi di masyarakat. Sedangkan museum Dewantara Kirti Griya melakukan kurasi dengan menitikberatkan gambar unggahan yang dianggap khas dan representatif untuk menarik minat pengguna media sosial. Selain itu, kedua Local Studies Center sebelumnya dan juga museum Sonobudoyo sepakat bila unggahan sebaiknya dapat mendapatkan likes yang signfikan sekaligus mengundang komentar yang konstruktif agar semakin meningkatkan visibilitas.

Meskipun belum memiliki media sosial maupun pengelolaannya secara mandiri, pengelola Hatta Corner mengakui dan menyadari pentingnya media sosial sebagai upaya membuka akses yang lebih besar serta meningkatkan visibilitas (Massis 2014) atas koleksi warisan budaya yang dimiliki dan kebanyakan juga dalam bentuk fisik. Dengan meningkatnya visibilitas, kesadaran pengguna akan pentingnya kelestarian dan keberlanjutan keberadaan koleksi dapat terus ditingkatkan dan dijaga relevansinya.

\section{Ketertarikan dan peningkatan kesadaran pengguna pada koleksi}

Dari hasil analisa serta pemetaan atas pemanfaatan Local Studies Center di atas, dapat dikatakan bahwa sebagian besar Local Studies Center pada dasarnya telah memahami pentingnya manfaat media sosial sebagai bagian dari promosi koleksi yang dapat membuka akses yang jauh lebih besar, mudah dan cepat. Pengelola juga menyadari dengan 'pasar' pengguna muda di Indonesia yang besar, memanfaatkan media sosial memberikan kesan yang lebih relevan atas keberadaan institusi dan koleksi yang dimiliki.

Berdasarkan hasil wawancara dengan pengelola informasi pada Local Studies Center, diketahui bahwa target implementasi media sosial adalah anak muda. Seperti riset sebelumnya yang dilakukan oleh (Stuedahl, Education, \& Lowe, 2014) yang berusaha menarik minat generasi muda untuk datang pada museum dengan menggunakan media sosial. Hasil dari riset menunjukkan peningkatan signifikan dari pengunjung muda setelah pengelola menggunakan media sosial. Lebih lanjut, pengelola informasi pada museum Dewantara Kirti Griya juga berharap besar dengan adanya media sosial dapat menarik minat kunjungan dari berbagai kalangan usia.

Dengan media sosial yang dapat memancing ketertarikan dari pengguna, maka secara tidak langsung pengguna juga dapat memperhatikan maupun melihat lebih jauh koleksi yang dipromosikan di dalamnya. Sehingga, pengguna secara tidak langsung dapat mencoba untuk belajar maupun memahami tentang keberadaan, nilai maupun informasi dari suatu koleksi yang merupakan warisan budaya. Dengan meningkatnya pengetahuan atas koleksi warisan budaya tersebut, maka kesadaran pengguna atas pentingnya kelestarian koleksi tersebut akan tumbuh secara bersamaan. Dengan demikian, media sosial memiliki peran yang bermanfaat dalam menumbukan kesadaran pentingnya upaya melestarikan koleksi warisan budaya dan secara tidak langsung juga dapat membuka akses, peluang maupun tantangan lainnya. Koleksi warisan budaya maupun upaya pelestariannya yang sebelumnya kurang mendapatkan perhatian ataupun tidak diketahui, menjadi relevan dan dapat disadari keberadaan maupun pentingnya oleh pengguna. 


\section{KESIMPULAN}

Media sosial memiliki peranan penting dalam era dimana perkembangan teknologi berlangsung dengan cepat, masif dan menyeluruh. Local studies center merupakan institusi yang memiliki tanggung jawab terhadap koleksi sumber informasi. Sebagian besar diantaranya merupakan warisan budaya yang bernilai historis, langka dan penting. Sejumlah upaya pelestarian baik dari sisi fisik maupun informasi telah dihelat oleh local studies center dengan berbagai dinamika dan keterbatasan yang dimiliki. Tantangan yang muncul bagi para pengelola informasi di Local Studies Center adalah pelestarian isi koleksi dan penyajian konten digital yang menarik bagi pengguna. Sebagai bagian dari upaya pelestarian, local studies center dapat memaksimalkan peran media sosial untuk membangun kesadaran pengguna mengenai pentingnya upaya dan peran pelestarian itu sendiri sekaligus menjadi sarana komunikasi untuk menjaga relevansi warisan budaya yang menjadi koleksi baik dengan pengguna maupun semua pihak terkait. Dengan meningkatnya kesadaran dan kemampuan untuk menjaga relevansi dengan kondisi terkini, maka koleksi warisan budaya memiliki kesempatan yang lebih besar untuk tetap lestari.

\section{DAFTAR PUSTAKA}

Ahenkorah-Marfo, M., \& Akussah, H. (2016). Being where the users are Readiness of academic librarians to satisfy information needs of users through social media. Library Review, 65(8/9), 549-563.

Anderson, K. E. (2016a). Getting acquainted with social networks and apps: picking up the Slack in communication and collaboration. Library Hi Tech News, 33(9), 6-9.
Anderson, K. E. (2016b). Getting acquainted with social networks and apps: Instagram's instant appeal. Library Hi Tech News, 33 (3), 11-15.

Asosiasi Penyelenggara Jasa Internet Indonesia. 2017. Infografis: Penetrasi \& Perilaku Pengguna Internet Indonesia yang diakses pada https://www.apjii.or.id/ tanggal 27 Februari 2017.

Kwanya, T., Stilwell, C., \& Underwood, P. G. (2015). Library 9.6: Intelligent Libraries and Apomediation. UK: Chandos Publishing.

Lamont, L., \& Nielsen, J. (2015). Calculating value: a digital library's social media campaign. The Bottom Line: Managing Library Finances, 28 (4), 106-111.

Li, E. Y., Loh, S., Evans, C., \& Lorenzi, F. (2013). Organizations and Social Networking: Utilizing Social Media to Engage Consumers (pp. 1-445). Hershey, PA: IGI Global. doi:10.4018/978-1-4666-4026-9

Lowe, Sarah. (2014). Social Media as Resources for Involving Young People in Museum Innovation: A Cultural Studies Approach to CoDesign. International Journal of Sociotechnology and Knowledge Development, 6(3), pp. 60-80. DOI: 10.4018/ijskd.2014070104

Massis, B. E. (2014). Library marketing: moving between traditional and digital strategies. New Library World, 115(7/8), 405-408.

Mi, J., \& Nesta, F. (2006). Marketing library services to the Net Generation. Library Management, 27(6/7), 411-422. 
Perez, Martin Julius V. (2012). Local Studies Centers: Transforming History, Culture and Heritage in the Phillippines, World Library and Information Congress: IFLA, Helsinki, 31 May 2012.

Ress, S. (2015). Special Collections: Improving Access and Usability. The reference Librarian, 56(1). DOI: 10.1080/02763877.2015.968757

Sriram, V. (2016). Social Media and Library Marketing: Experiences of KN Raj Library. Journal of Library \& Information Technology, 36(3), pp.153-157. DOI: 10.14429/ djlit.36.3.9810

Stewart, C. (2012). Preservation and Access in an Age of E-Science and Electronic Records: Sharing the Problem and Discovering Common Solutions. Journal of Library Administration, 96:7-4, pp. 265-278. DOI:

10.1080/01930826.2012.684505

Stuedahl, D., Education, T., \& Lowe, S. (2014). A Cultural Studies Approach to Co-Design Social Media as Resource for Involving Young People in Museum Innovation :, 6(September), 60-80. http://doi.org/10.4018/

ijskd.2014070104 